\title{
Identification of zones with high potential for biological diversity on dormant forested landslides
}

\author{
Wiktor Tracz ${ }^{1}(1) \cdot$ Wojciech Ciurzycki ${ }^{2} \cdot$ Piotr Zaniewski $^{2} \cdot$ Łukasz Kwaśny $^{1} \cdot$ Katarzyna Marciszewska $^{2}$. \\ Jerzy Mozgawa ${ }^{1}$
}

Received: 26 June 2018 / Revised: 7 December 2018 / Accepted: 24 January 2019 / Published online: 18 March 2019

(c) The Author(s) 2019

\begin{abstract}
Landslides and erosion processes cause a high level of morphological diversity which, over the course of time, results in an increased level of forest species and habitat biodiversity. According to the principles of landscape ecology, information concerning points of convergence-understood as transition zones between elementary parts of a slope-could be interpreted as a surrogate for biodiversity. To recognize locations of land surface disruption, points of convergence derived from a high-resolution digital elevation model (DEM) were used in the research. It was assumed that relationships exist between landslide geodiversity and biodiversity and that from the DEM it is possible to select bare-earth surface structures where points of convergence can be identified. In order to verify this hypothesis, indicators of biodiversity such as richness of plant species and species diversity were checked. Based on the spatial distribution of points of convergence, locations of sample plots were planned and these indicators were verified during fieldwork. Samples were taken both in areas with a high concentration of points of convergence and in areas with a low concentration (or absence) of points of convergence. The results show that species diversity in the areas having a high concentration of points of convergence was significantly higher than in the areas having a low concentration of points of convergence. The proposed method allows the selection of parts of forested landslides that have the potential to develop a high level of biological diversity; it thus supports the management of areas of forest ecosystems with high levels of biodiversity within the scope of a cutting system. This may entail avoiding the traversal of areas that potentially possess high biological diversity with skid roads, preserving parts of these areas with thick vegetation for forest game purposes or leaving predominant and dead trees. The proposed method may also be used in scientific research into processes of biodiversity appearing on forested landslides.
\end{abstract}

Keywords Forested landslide $\cdot$ DEM $\cdot$ Geodiversity $\cdot$ Biodiversity $\cdot$ Species diversity $\cdot$ Points of convergence $\cdot$ Management support

Communicated by Arne Nothdurft.

Wiktor Tracz

wiktor.tracz@wl.sggw.pl

1 Department of Geomatics and Land Management, Faculty of Forestry, Warsaw University of Life Sciences - SGGW, 159 Nowoursynowska str., bld. 34, 02-776 Warsaw, Poland

2 Department of Forest Botany, Faculty of Forestry, Warsaw University of Life Sciences - SGGW, 159 Nowoursynowska str., bld. 34, 02-776 Warsaw, Poland

\section{Introduction}

Information regarding places with high levels of biological diversity is much needed and is frequently used in the management of valuable parts of the natural environment. A set of Essential Biodiversity Variables (EBVs) proposed by the Group on Earth Observations Biodiversity Observation Network (GEO BON) is one example (Pereira et al. 2017). Sophisticated forms of adaptive management are required to ensure that conservation efforts fully consider the value of geodiversity for supporting biodiversity (Comer et al. 2015). Biological diversity is widely understood as variability among living organisms. Biodiversity may be defined at three levels of organization, which are genetic diversity, species diversity and ecosystem diversity (World Conservation 
Monitoring Centre 1992). Biodiversity may also be considered as having compositional, structural and functional components (Noss 1990), which are interdependent and determined by three primary attributes of ecosystems (Franklin et al. 1981). This study focuses on species-level diversity and the compositional component of biodiversity.

The influence of geodiversity on biodiversity is critical. Geosites create a diversity of microenvironments that enhance species richness (Hjort et al. 2015). Alexandrowicz and Margielewski (2010) state that landslides and erosion processes cause a high level of geodiversity which, over the course of time, results in an increased level of forest species and habitat diversity. Landslides change sites, soil and vegetation and as agents of environmental change also create site diversity (Geertsema and Pojar 2007). The exposed soil is a place of succession through which new plant communities can emerge. The communities existing after landslides may differ significantly from those that existed there previously or that exist in areas adjacent to those covered by a landslide (Schuster and Highland 2017). New communities create the possibility of the existence of new species, so an increase in the diversity of communities increases species diversity. Moreover, a multiplicity of different communities also increases biodiversity. Results of broad investigations dealing with natural disturbances and their impact on vascular plant enrichment at two climatically contrasting Andean ranges revealed that the main triggers for additional input of pioneer species during succession stages initiated by perturbations are landslides and mudflows (Richter 2009).

Recent studies have shown that in wooded areas, airborne laser scanning of the earth's surface (known as ALS or Lidar-Light Detection and Ranging) has become an appropriate and mature technical tool for documenting bare-earth micro-topographical features (Sittler et al. 2006; Doneus et al. 2008). Different methods of extraction or classification of landform elements have been used-for example, statistical analysis of variability of landform curvature (Tarolli et al. 2012), object-oriented image analysis (Drăguț and Blaschke 2006) and the application of fuzzy logic (MacMillan et al. 2000).

A new generation of high-resolution DEMs, calculated from Lidar data, is now widely available and could be utilized for deriving detailed information about the morphology of forested slopes. Primary geomorphometric attributes or parameters (Wilson and Gallant 2000) are used the most often for such purposes. For example, Dai and Lee (2002) described statistical relations of landslide frequency with the physical parameters contributing to the initiation of landslides and indicated that slope gradient, lithology, elevation, slope aspect, and land-use are statistically significant in predicting slope instability; Kasai et al. (2009) used the eigenvalue ratio filter and slope angle, calculated from Lidar-derived DEM, to characterize the geomorphic features of deep-seated landslides at various stages of evolution and activity and Von Ruette et al. (2011) used slope angle, planform curvature and contributing area, constructed from Lidar data, for modelling spatial incidence of landslides, triggered by an extreme rainfall. Secondary geomorphometric parameters (like Topographic Wetness Index and Terrain Ruggedness Index) have also been used (Różycka et al. 2017). Besides primary and secondary parameters, Glenn et al. (2006) used additional indexes (semivariance and fractal dimension) to examine the surface morphology of landslides.

According to the principles of landscape ecology (Farina 2006; Walz 2011), in places where heterogeneous habitat patches are connected, an enhancement of biodiversity exists. These places are called transition zones and include the ecotones or points of convergence that connect recognizable parts inside a landslide. An ecotone is a transition zone between two neighbouring areas with different ecological conditions, whereas a point of convergence ${ }^{1}$ (also called a covert) is a transition zone between three or more neighbouring areas with different ecological conditions (Forman and Godron 1986).

It is thus reasonable to posit the hypothesis that if the identification and mapping of transition zones on forested landslides is possible, the transformation of a DEM into a map of the spatial density of points of convergence could be a way of recognizing places where high biological diversity is expected to exist or to be created over the course of time.

The main goal of this work is to verify that an existing Lidar-derived DEM can be used for the recognition of valuable parts of forested landslides. Based on this information, such places may be checked by field investigation for proper management aimed at keeping or improving biological diversity. The conducted research focused mainly on the geodiversity of landslides and particularly on the spatial diversity of landslide topography. It was assumed that relationships exist between landslide geodiversity and biodiversity (understood here as species diversity) and that from the DEM it would be possible to select the bare-earth surface structures where points of convergence exist.

\footnotetext{
${ }^{1}$ It must be noted that the difference in the meaning of the word "convergence" in landscape ecology and morphology of a slope. In terms of the morphology of a slope units, convergence commonly occurs towards the middle of slope units, whereas divergence commonly occurs on boundaries of slope units.
} 


\section{Materials and methods}

\section{Methodological approach}

Landscape ecology proposes two different methodological approaches for analysis of the spatial organization and functioning of nature: the patches-matrix-corridors approach and the gradient approach. The patches-matrix-corridors model of a landscape perceives the landscape as mosaics composed of a number of landscape elements whose boundaries separate them from neighbours (Forman and Godron 1986; Farina 2006; Hoechstetter et al. 2008). The gradient approach describes the landscape through a set of analyses conducted for different spatial scales (Hoechstetter et al. 2011). Both approaches were selected here for analysis of forested landslides' spatial diversity.

The patches-matrix-corridors approach was selected for analysis of forested landslides' spatial diversity, because this study focuses on species-level diversity for a relatively small area, and there was no need to conduct an analysis for different spatial scales. The methodological approach starts from the hierarchy of a catchment's spatial structure and a focus on dormant landslides covered with forests. Forested landslides were analysed in this approach as if they were a special unit in the hierarchically organized landscape's spatial structure and were a special kind of forested landscape element. According to landscape ecology principles, the area of a landslide is a mosaic of a huge number of recognizable elementary parts of slopes (areal units), which we here call 'ecoslopes'. Established ecoslopes differ from each other in slope exposition and slope inclination. This approach is very similar to that involving the so-called slope facets calculated from combinations of DEM-derived slope, aspect and curvature used by Rowbotham and Dudycha (1998). Each element of the landslide morphology-e.g. main and minor scarps, reverse slopes, hummocky parts of the landslide colluvium and elements of the landslide drainage system — can consist of different numbers of ecoslopes. Places where three or more ecoslopes meet are recognized as points of convergence; they indicate transition zones where a discontinuity of the ecological conditions occurs and act as key points for biological movements in the landscape (Metzger and Muller 1996). The spatial distribution of points of convergence on a landslide is affected by geomorphology, the mosaic of soil deposits and the groundwater level, which shapes the spatial variability of moisture conditions.

Landslides were analysed as a whole, without distinguishing their morphological features. Only ecoslopes that possess a slope inclination of greater than $25^{\circ}$ were used in the analysis. It was also assumed that each of the eight aspects has the same degree of significance for influencing ecoslope formation; thus, weights were not defined for aspect classes.
Points of convergence were found as a result of DEM data processing.

We agree, however, with Hoechstetter et al. (2011) that near-natural and semi-natural landscapes are frequently organized in the form of ecological gradients. The potential for biodiversity has a continuous spatial character and changes gradually in geographical space. That is why the gradient approach was also used in this research. The spatial distribution of points of convergence was prepared, and this information was used instead of the locations of individual points. This makes it possible to recognize areas with potentially high concentration of microhabitats (where biodiversity is potentially high) and areas with potentially low concentration of microhabitats (where biodiversity might be rather low). In order to verify the proposed method of recognizing places (based on DEM processing) where a high potential for biological diversity exists, the locations of phytosociological relevés (sample plots) were planned, and species richness and species diversity were calculated for them.

\section{Study area}

The study area was located in the Polish Outer (Flysch) Carpathians, where a vast number of mass movement phenomena $(20,000-30,000)$ exist. It is a part of the largest landslide region in Poland, with an area of over 1300 ha (Zabuski et al. 1999). The geographic distribution of landslides was available from the database prepared with geological field mapping as part of the Landslide Counteracting System/SOPO nationwide programme (Polish Geological Institute 2018).

The SOPO database was carefully analysed, and six landslides covered with forest situated in the watershed of Bonarówka Creek (Podkarpackie Province, Poland) were selected (Fig. 1). The elevation range of the study area is approximately $240-410 \mathrm{~m}$ a.s.1., and its total area is $126.5 \mathrm{ha}$. Analysed landslides are located on hills with angles of slope inclination between $0^{\circ}$ and $53^{\circ}$. Landslides 183 and 539 are located on slopes having a northeastern exhibition, and landslides 149 and 150 on southwestern slopes. Landslide 151 is located on a northwest slope, and landslide 173 on a slope having northwestern and northeastern exhibition. The oldest dated landslide movements in the study area appeared around the year 1850 (Bober et al. 1977).

As is true for most Carpathian landslides, the six analysed landslides belong to old forms, occurring on mountain slopes formed from the Late Glacial to Middle Holocene (Grabowski et al. 2008). In terms of geological construction, landslides located in the study area are complex, debris slide and dormant. They are mostly covered with a multi-species mixed forest dominated by pine-fir-beech stands that have dense understory. The earliest information about forests in the study area comes from the end of the eighteenth Century (Karte des Königreichs Galizien und Lodomerien 1779). 


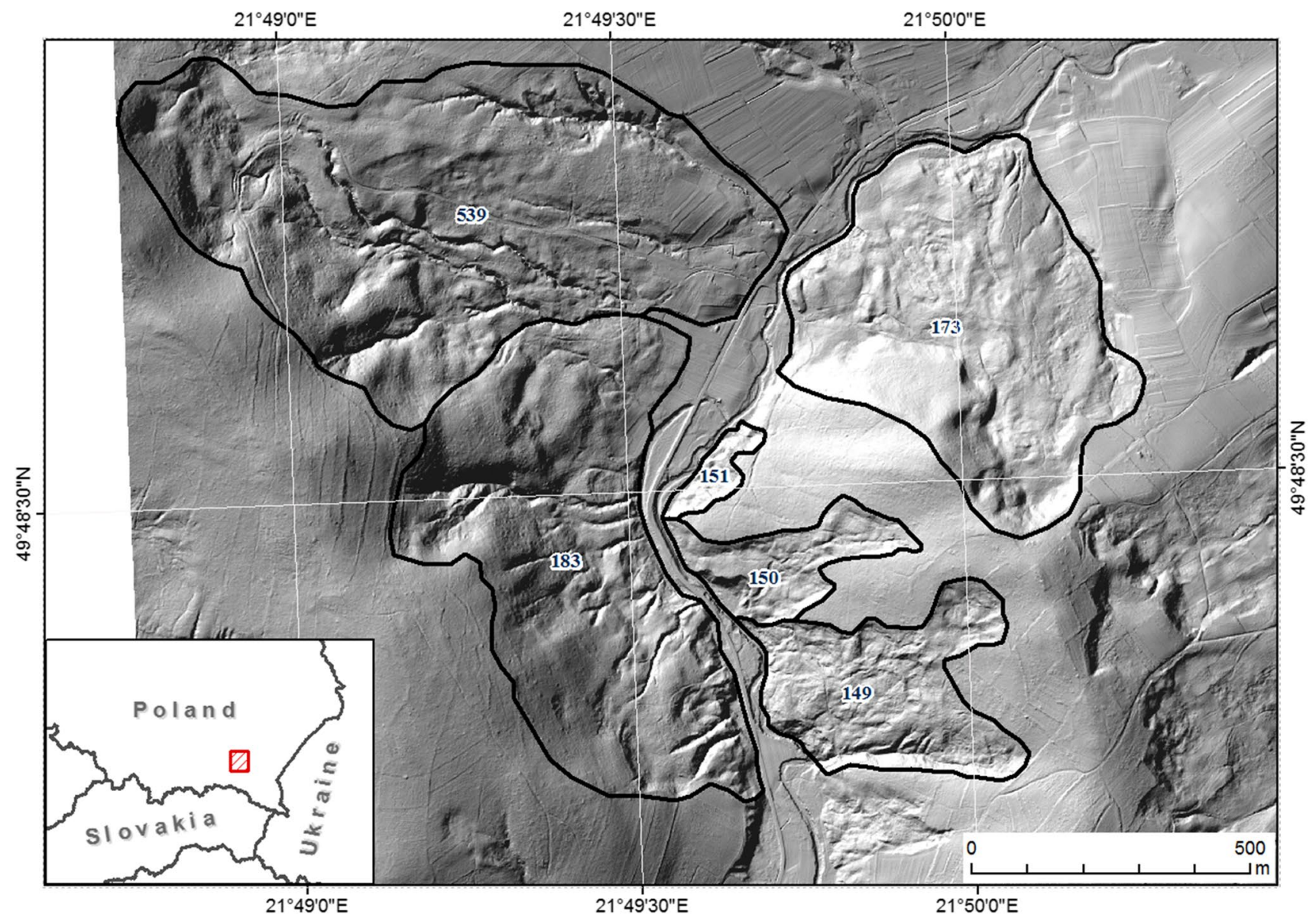

Fig. 1 Location and boundaries of six analysed landslides, with their numbers presented on a shaded relief

\section{Spatial data processing}

The ALS DEM was found to be extremely accurate and potentially very useful in forestry (Reutebuch et al. 2003; Stereńczak 2010; Pereira and Gonçalves 2010). The research used a high-resolution DEM derived from airborne laser scanning (acquired in 2012). The DEM that is available as $1 \mathrm{~m}$ ground resolution raster data with ca $0.20 \mathrm{~m}$ height accuracy from the IT System of the Country's Protection Against Extreme Hazards (ISOK) (National water management authority 2018) was utilized. As ancillary data, both an orthophotomap prepared from digital colour aerial photographs recorded in 2009 with a ground resolution of $0.20 \mathrm{~m}$ as well as digital forest maps were also used.

As mentioned above, appropriate information regarding the location of points of convergence must be obtained in order to allow the identification of valuable parts of forested landslides. Data processing (performed with ArcGIS 10 package) consists of several steps: deriving slope and aspect from the DEM, creating ecoslope polygons, selecting the localization of points of convergence, and mapping the spatial distribution of points of convergence. A detailed description of data processing follows.

Slope exposition (aspect), slope inclination (slope) and shaded relief rasters were derived from the DEM. Next, the slope was reclassified into one of two classes: an area with slope inclination of less than $25^{\circ}$ or an area with slope inclination of more than $25^{\circ}$.

The raster of slope exposition (aspect) was reclassified and nine classes were created. Flat areas constituted one class of aspect, and the eight remaining classes corresponded to compass directions. Each of these eight aspect classes had its central axis on N, NE, E, SE, S, SW, W or NW and was denoted with an azimuth angle of $22.5^{\circ}$ on either side of it.

Next, the layer of ecoslopes was created. Ecoslopes differ from each other in slope exposition and slope inclination. Ecoslopes were created for areas with slope inclination of more than $25^{\circ}$ having one of 8 defined aspects. As the result of aspect and slope data overlaying, a polygon layer of ecoslopes was prepared. Each polygon in the ecoslope layer had one of nine unique values of coding (Fig. 2).

In order to derive the locations of points of convergence, the vertices of ecoslope polygons were separated and saved 


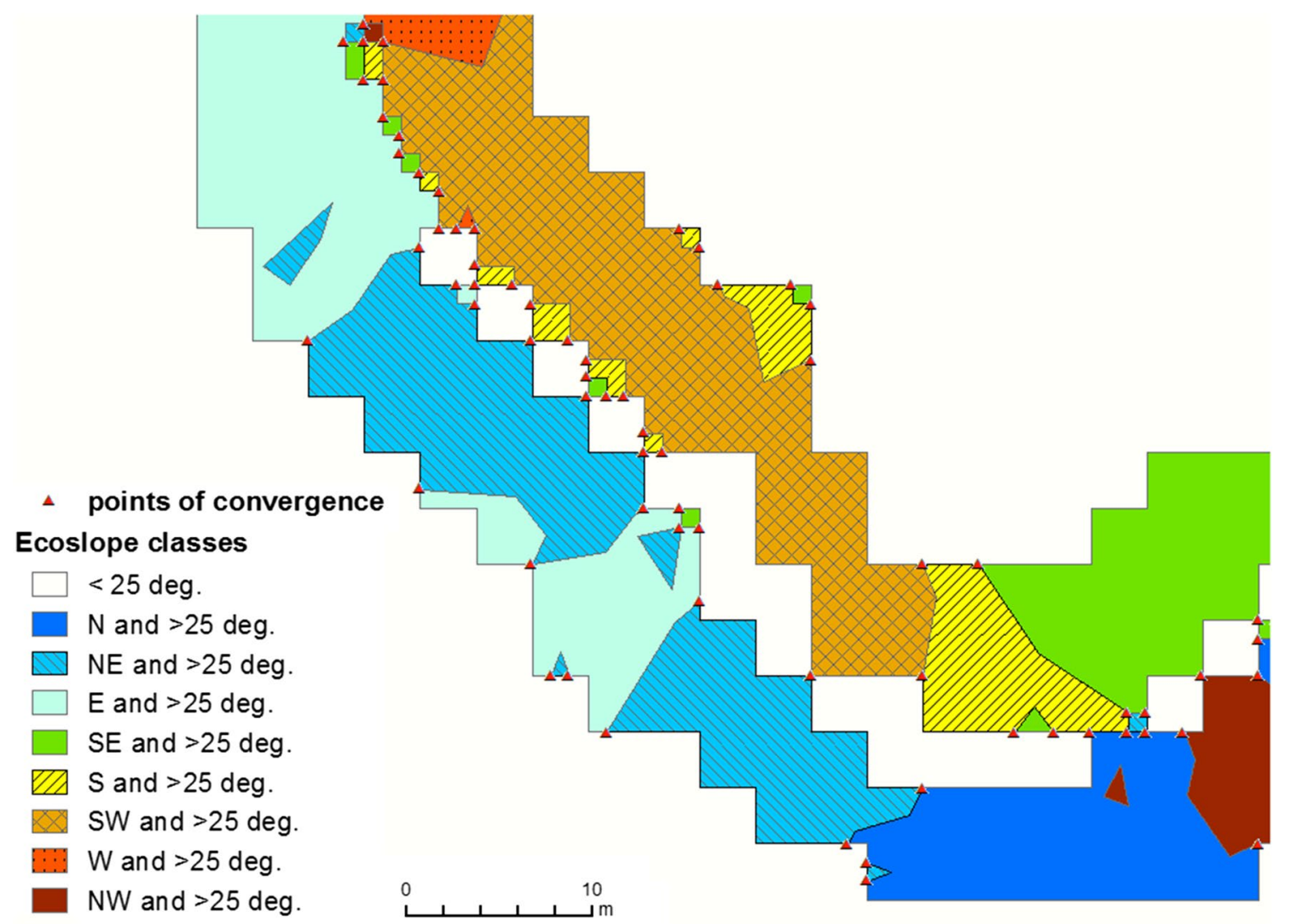

Fig. 2 Ecoslope polygons, their classes and locations of points of convergence: a small area example

as points. Only vertices that represented locations where three or more ecoslopes met were selected for further analysis (see Fig. 2). 12,526 points of convergence were found (Fig. 3).

The spatial distribution of points of convergence was transformed into a density map, which allows the recognition of areas with potentially high and low concentrations of microhabitats. A density map was created based on a point density analysis (Silverman 1986). The total number of points of convergence was calculated for each 5-m cell of the resulting raster, while the neighbourhood of each processed cell was defined as a $50 \times 50 \mathrm{~m}$ rectangle. The density map was used to select sample plot locations, where phytosociological relevés were made during fieldwork and plant species diversity was verified.

The areas with high concentration of points of convergence (group A) were defined as those where the numbers of points of convergence were greater than the median (which equalled 64) calculated for the analysed range of values [1-127]. The areas with a low concentration of points of convergence (group B) were defined as those where the number of points of convergence was less than the median of the value range (Fig. 4).
The map enabled the selection of plot locations and the visualization and analysis of the spatial distribution of places with potentially high biodiversity value.

\section{Fieldwork and data preparation}

In order to verify the methodology presented here-i.e. determination of the spatial density of points of convergence (based on DEM processing) to enable identification of places where high biological diversity can be expected to exist - the richness of plant species and species diversity were verified during fieldwork. Fieldwork was conducted in the summer of 2015. A total of 32 sample plots (Fig. 4) were randomly established while guaranteeing following: there were 16 samples taken in areas with a high concentration of points of convergence (group A) and another 16 samples taken in areas with a low concentration (or absence) of points of convergence (group B). Plot locations in the field were determined using a Trimble Pathfinder ProXH receiver. Positioning accuracy did not exceed $0.3 \mathrm{~m}$, which is acceptable and is typical for the structure of forests covering the study area (Brach 2012). Vegetation was sampled on the $100 \mathrm{~m}^{2}$ plots using the Braun-Blanquet (1928) method, as modified by Barkmann et al. (1964). 


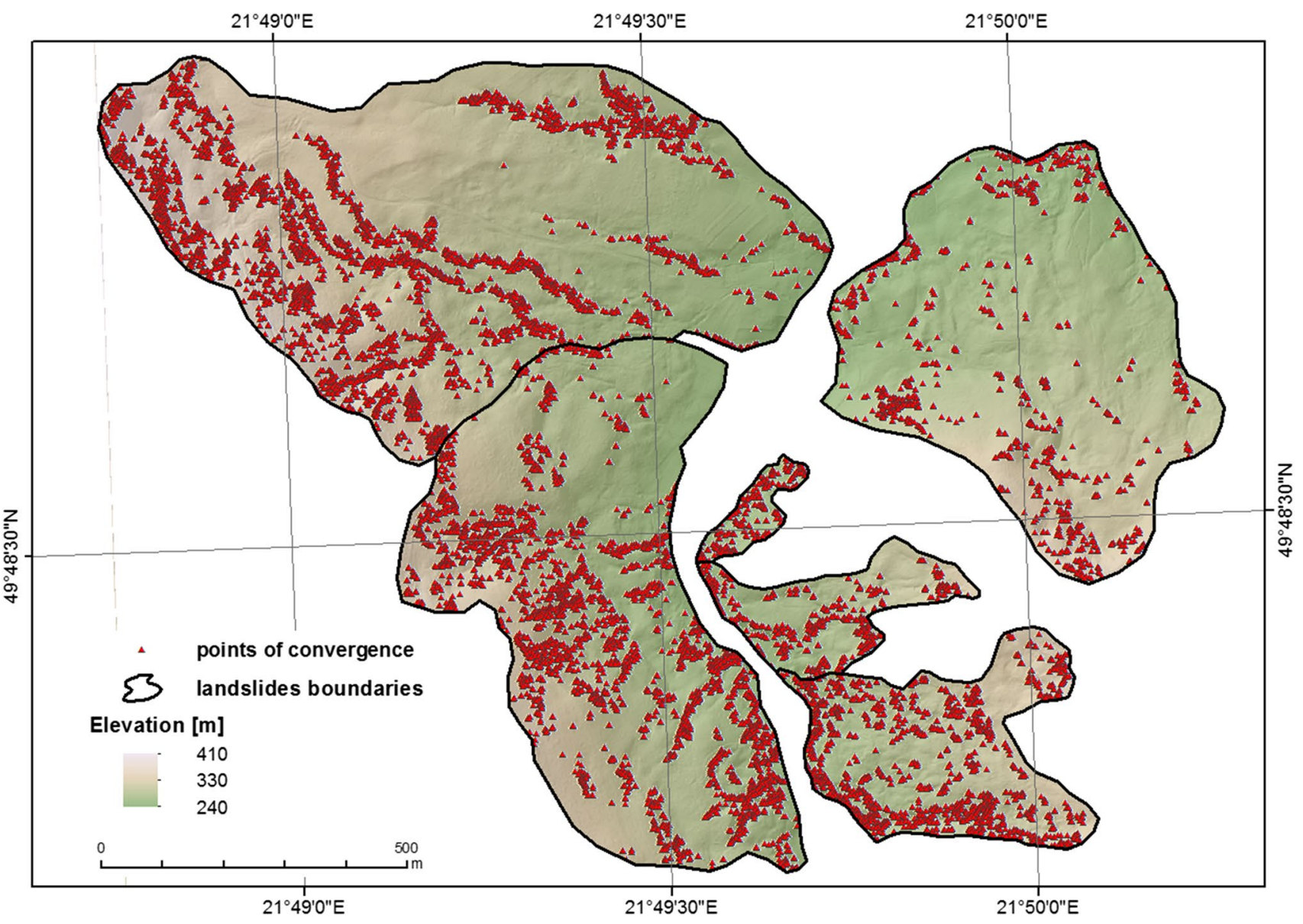

Fig. 3 Spatial distribution of points of convergence in the study area

The data were transformed using an arithmetic method (Tüxen and Ellenberg 1937), i.e. mean (middle) values were assumed for each species cover interval. The existence of differences in species diversity for the two analysed groups was checked by comparison of Simpson and Shannon alpha diversity indices (Magurran 1988) with the Mann-Whitney test using PAST software (Hammer et al. 2001). The richness of plant species of both groups of samples was calculated and compared using the rarefaction curve method for binominal (presence-absence) data (Colwell et al. 2012) in the EstimateS 9 software (Colwell 2013). A rarefaction curve shows the statistical relationship (probability) between increase in the occurrence of new species and increase in total sampled area. It is an alternative method of species richness measurement, compared to the basic measurement of the number of species within each plot.

\section{Results}

The primary intended result of the presented method is determination of the spatial density of points of convergence (Fig. 4), which make it possible to recognize parts of forested landslides that have the potential to develop a high level of biological diversity. In order to verify the method, species diversity and species richness were calculated for two analysed groups of samples.

A total of 124 species of vascular plants and 23 species of bryophytes were found during fieldwork in the 32 sample plots. Sixteen of these plots belonged to group A and another 16 to group B (see 'Fieldwork and data preparation' section).

A statistically significant, positive dependence was found between the most commonly used indicators of biodiversity (Simpson, Shannon) and the density of points of convergence (Fig. 5a, b). The same positive dependence was found for the basic measure of species richness, presented as the number of species in a sample (Fig. 5c).

The richness of plant species for two groups of samples can be determined with a rarefaction curve method. Values 


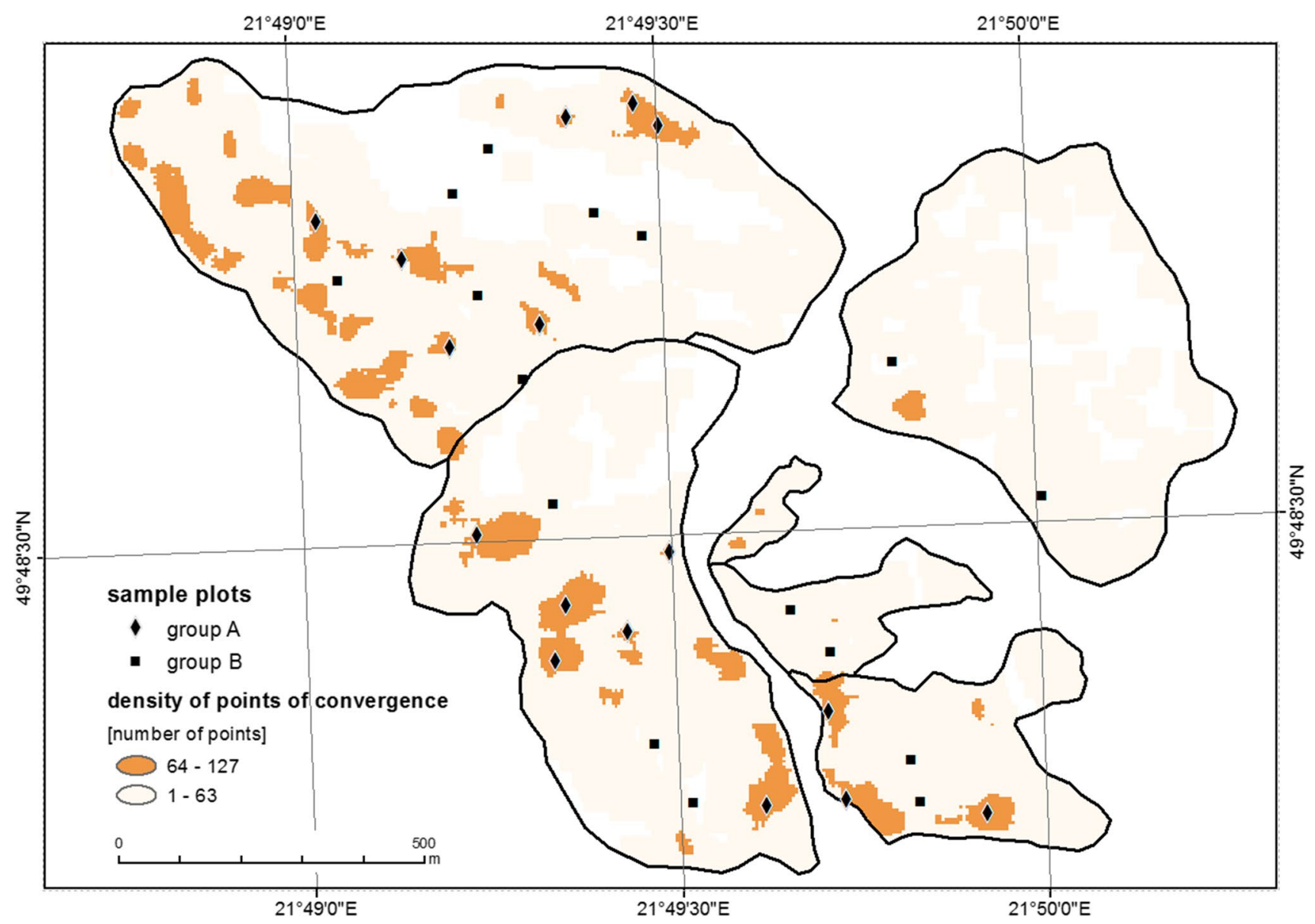

Fig. 4 Spatial density of points of convergence and locations of sample plots belonged to two groups (see description in the text)

of the calculated density of points of convergence were divided into two subsets (groups A and B) using the median. The species richness of plots compared with the rarefaction curves is significantly higher for areas with a high concentration of points of convergence (group A) than for areas with low concentration of points of convergence (group B); the 95\% confidence intervals do not overlap (Fig. 6).

The species diversity alpha of the areas belonging to group A is also significantly higher than that of the areas belonging to group B. Group A has significantly higher values of both Simpson and Shannon indices $(p<0.001$ in the Mann-Whitney test). The values of both indicators are presented with the interquartile range (IQR) method (Fig. 7).

\section{Discussion and conclusion}

The presented method uses products derived from a highresolution DEM to determine places of potentially high biodiversity value within the landslide area covered by forest, which hypothetically occur where a high concentration of points of convergence is recognized.
In order to recognize areas with potentially high biological diversity, two data sets may be used, which are ecotones and points of convergence. By definition, an ecotone is a transition zone between two neighbouring areas with different ecological conditions, while a point of convergence is a transition zone between three or more neighbouring areas with different ecological conditions. Points of convergence were chosen for analysis in the present research because they represent places with potentially higher biological diversity than those represented by ecotones.

The DEM utilized in the research was deduced from a cloud of Lidar points that represent the bare earth at some level of detail. The vertical and horizontal accuracy of the DEM and data generated from the DEM are important for evaluation of the proposed method. The value of the vertical accuracy of the ALS DEM obtained for forest-covered terrain has been investigated by numerous studies (Reutebuch et al. 2003; Stereńczak 2010; Pereira and Gonçalves 2010). They pointed out that a DEM accuracy of $0.10-0.30 \mathrm{~m}$ (which increases slightly with canopy density) can be expected, and the ALS DEM was found to be extremely accurate and potentially very useful in forestry. The level 

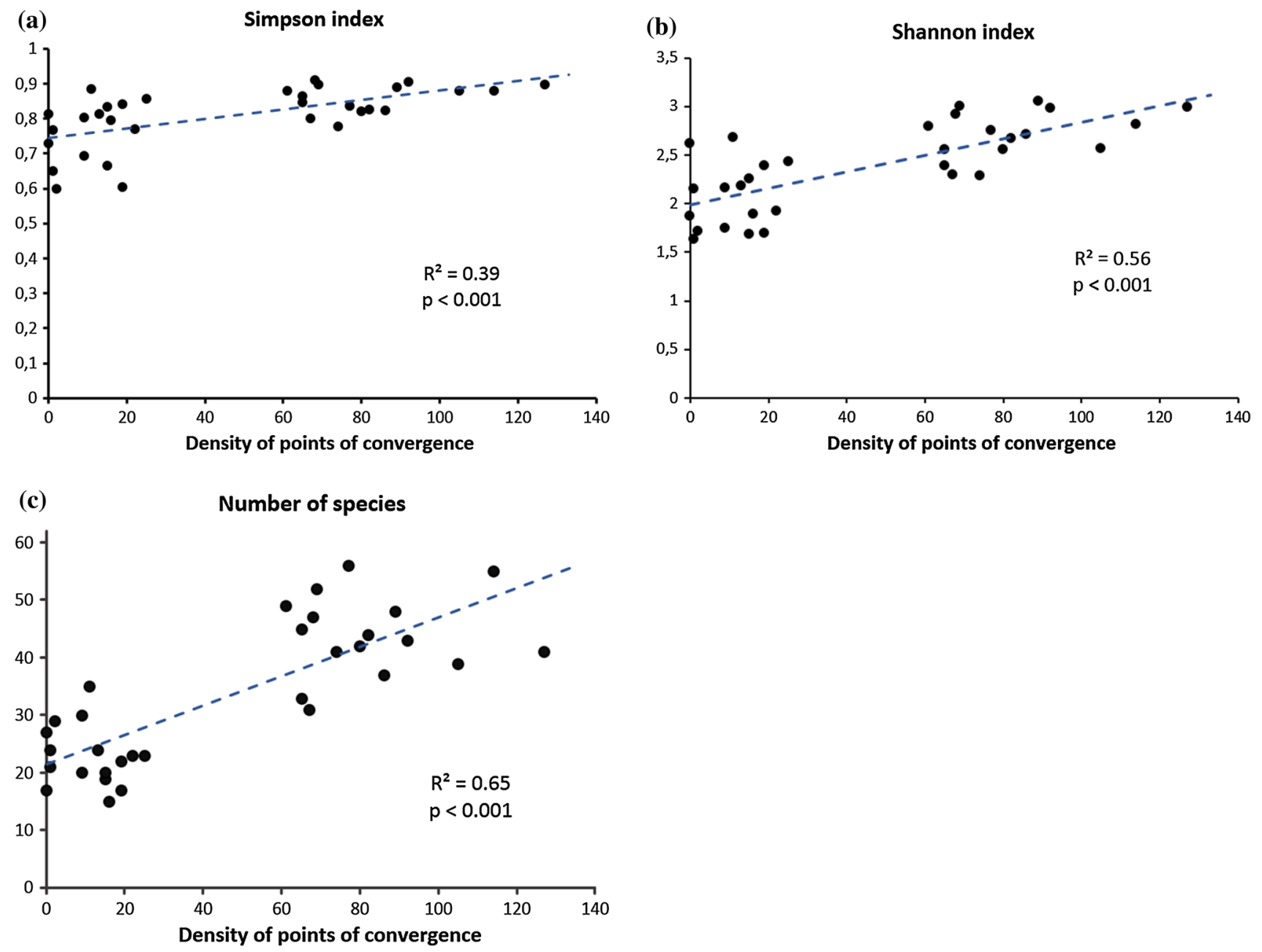

Fig. 5 Relationships between density of points of convergence and three indicators of biodiversity: a Simpson, $\mathbf{b}$ Shannon and $\mathbf{c}$ number of species

Fig. 6 Richness of flora species on the sample plots in areas with high concentration of points of convergence (group A) and areas with low concentration of points of convergence (group B), presented using rarefaction curves

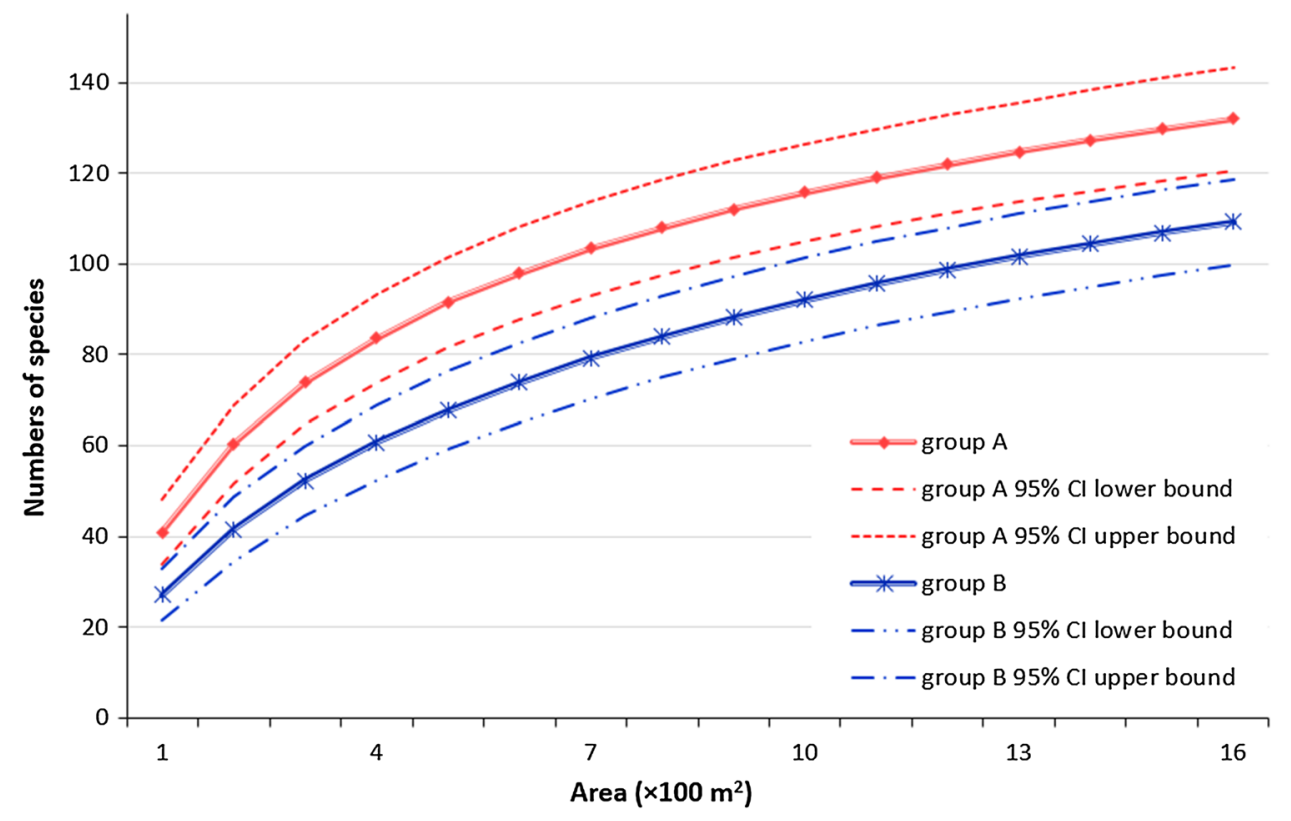


(a)

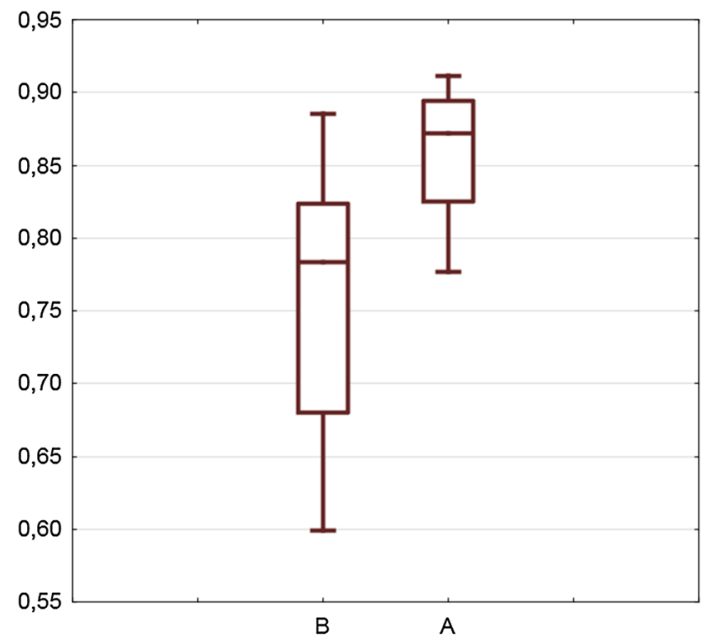

(b)

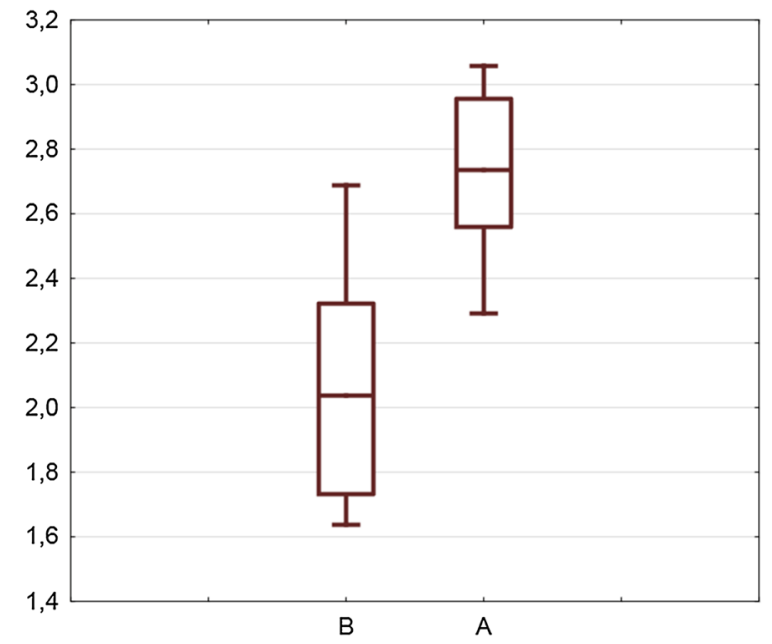

Fig. 7 Species diversity alpha of areas belonging to group A and areas belonging to group B, presented with the interquartile range method: a Simpson index values and $\mathbf{b}$ Shannon index values

of DEM vertical accuracy obtained by the abovementioned research is similar to the accuracy parameters equalling $0.20 \mathrm{~m}$ for the ISOK nationwide programme (National water management authority 2018) for an ALS point cloud density of $4 \mathrm{pts} / \mathrm{m}^{2}$.

The horizontal accuracy of locations of points of convergence depends on the source data (of which the DEM is the main one) and the accuracy of the several data processing operations used-namely, DEM interpolation from Lidar data, aspect and slope calculation, raster-to-vector conversion. DEM interpolation from Lidar data has been recognized as having an accuracy of $0.17-0.25 \mathrm{~m}$, which depends on the spatial resolution of the data (Bater and Coops 2009). Raster-to-vector conversion creates polygons that contain a minimum number of segments, while remaining as close as possible to the original raster cell edges (ESRI 2018); it has an accuracy of around 0.5 of raster cell size, which for the data used in the research equals $0.5 \mathrm{~m}$. The point density analysis used in the research (see 'Study area' section) may be recognized as a source of inaccuracy; it introduces some generalization of information in the form of a density map, a raster with $5 \mathrm{~m}$ cell size (the input raster had $1 \mathrm{~m}$ resolution).

All the other sources of inaccuracy mentioned above introduce less error than point density analysis. However, applying point density analysis is justifiable. The potential for biodiversity changes gradually in geographical space, so a density map (obtained as the result of point density analysis) provides more conveniently usable information than the precise locations of all points of convergence.

In this study, the landslides were analysed as a whole, without dividing them into parts. However, future works may be dedicated to relating ecoslopes to the different parts into which a landslide may be divided. For example, floristic richness can be evaluated for each slope units which are a type of morphological terrain units bounded by drainage and divide lines (Carrara 1988; Guzzetti et al. 1999). Slope units are related to the hydrological and geomorphological conditions and processes that shape natural landscapes Alvioli et al. (2016). Floristic richness can be evaluated also for areas with similar aspects (e.g. corresponding to 8 compass directions) or areas with similar slope (e.g. $10^{\circ}-20^{\circ}$ and $20^{\circ}-30^{\circ}$ ). Aspect and slope zonation may be important, because aspect and slope form thermal and moisture conditions on landslides. Future research may also consider using structural diversity metrics (Noss 1990) together with compositional diversity metrics for identification of places with high potential of phytodiversity. Structural diversity metrics may be prepared based on canopy height metrics calculated directly from Lidar data (Hyde et al. 2006; Bergen et al. 2009).

In reality, the transition zones that hypothetically exist between patches created by ecoslopes have a typically fuzzy character. Points of convergence should therefore be interpreted as the rough geographical location of the transition zones between relatively homogenous ecotopes.

The main simplification of the proposed method relates to the mismatch between the nature of transition zones and the DEM processing methods available in GIS. Future research in this area should thus take into account the uncertainty, vagueness and fuzziness of data used in analyses where methods such as rough set theory (Pawlak 1982) and fuzzy logic (Zadeh 1965) may be appropriate. The high degree of spatial diversity of landslides' topography, just like that obtained in this study for points of convergence, suggests the use of multifractal analysis for spatial pattern quantification 
and objective comparison (Brown et al. 1992; Xia et al. 2006; De Wang et al. 2010).

The key challenge for practical utilization of the proposed method involves the ways in which information on spatial density may be transformed into forest management actions that support biodiversity. All the analysed landslides are covered with fir-beech mixed forest (regeneration class) stands. Several different cutting systems are used in mountain forests where landslides occur (Smith 1962; Schütz et al. 2016). One of them is the irregular shelterwood cutting system that is used in the area subject to this research. This cutting system itself creates suitable conditions for natural regeneration. The spatial structure of stands subject to the irregular shelterwood cutting system is highly complicated.

In accordance with the ecological principles applied in forest practice, information about places with the potential to possess high biological diversity should be appropriately utilized in forest management. The presented method provides information about places with high geodiversity-which are, in reality, the same as microhabitats with potentially high biological diversity - that can be used in protecting valuable parts of landslides covered by forest. Protection of the selected places would be realized within the framework of the cutting system utilized in an area where landslides occur. In particular, this may entail avoiding the traversal of areas that potentially possess high biological diversity with skid roads, preserving parts of these areas with thick vegetation for forest game purposes, leaving predominant and dead trees and introducing biocenotic forest trees and shrub species.

The proposed method of DEM data processing, which allows the recognition of places with potentially high biodiversity value, may be employed for the management of microhabitats within the scope of cutting systems and in scientific research into processes of biodiversity formation on forested landslides. Utilization of the proposed method for the protection of microhabitats would involve the use of cartographical information regarding the spatial density of points of convergence by foresters; the possibility of the proposed method being utilized in research on biodiversity would depend on access to information about the spatial arrangement of points of convergence.

Open Access This article is distributed under the terms of the Creative Commons Attribution 4.0 International License (http://creativeco mmons.org/licenses/by/4.0/), which permits unrestricted use, distribution, and reproduction in any medium, provided you give appropriate credit to the original author(s) and the source, provide a link to the Creative Commons license, and indicate if changes were made.

\section{References}

Alexandrowicz Z, Margielewski W (2010) Impact of mass movements on geo-and biodiversity in the Polish Outer (Flysch) Carpathians. Geomorphology 123:290-304

Alvioli M, Marchesini I, Reichenbach P, Rossi M, Ardizzone F, Fiorucci F, Guzzetti F (2016) Automatic delineation of geomorphological slope units with r.slopeunits v1.0 and their optimization for landslide susceptibility modeling. Geosci Model Dev 9:3975-3991. https://doi.org/10.5194/gmd-9-3975-2016

Barkmann JJ, Doing H, Segal S (1964) Kritische Bemerkungenund Vorschläge zur quantitativen Vegetationsanalyse. Acta Bot Neerl 13:394-419

Bater Ch, Coops N (2009) Evaluating error associated with lidarderived DEM interpolation. Comput Geosci 35:289-300

Bergen K, Goetz S, Dubayah R, Henebry G, Hunsaker C, Imhoff M, Nelson R, Parker G, Radeloff V (2009) Remote sensing of vegetation 3-D structure for biodiversity and habitat: review and implications for lidar and radar spaceborne missions. J Geophys Res 114:G00E06. https://doi.org/10.1029/2008jg000883

Bober L, Chowaniec J, Oszczypko N, Witek K, Wójcik A (1977) Geologiczne warunki rozwoju osuwiska w Brzeżance koło Strzyżowa. Przegląd geologiczny 25(7):372-377

Brach M (2012) Accuracy analysis for determination of coordinates by the selected GNSS receivers in the forest environment. Sylwan 156(1):47-56

Braun-Blanquet J (1928) Pflanzensoziologie grundzüge der vegetationskunde biologische studienbücher 7. Springer, Berlin

Brown G, Michon G, Peyrière J (1992) On the multifractal analysis of measures. J Stat Phys 66:775-790

Colwell R (2013) EstimateS: statistical estimation of species richness and shared species from samples. Version 9. User's guide and application available online at http://purl.oclc.org/estimates. Accessed 25 May 2018

Colwell R, Chao A, Gotelli N, Lin S-Y, Mao CX, Chazdon R, Longino JT (2012) Models and estimators linking individual-based and sample-based rarefaction, extrapolation and comparison of assemblages. J Plant Ecol 5:3-21

Comer P, Pressey R, Hunter JRM, Schloss C, Buttrick S, Heller N, Tirpak J, Faith D, Cross M, Shaffer M (2015) Incorporating geodiversity into conservation decisions. Conserv Biol 29(3):692-701

Dai F, Lee C (2002) Landslide characteristics and slope instability modeling using GIS, Lantau Island, Hongkong. Geomorphology 42:213-228

Doneus M, Briese Ch, Fera M, Janner M (2008) Archaeological prospection of forested areas using full-waveform airborne laser scanning. J Archaeol Sci 35:882-893

Drăguţ L, Blaschke T (2006) Automated classification of landform elements using object-based image analysis. Geomorphology 81(3):330-344. https://doi.org/10.1016/j.geomo rph.2006.04.013

ESRI (2018) ArcGIS 10 desktop online help: raster to polygon (conversion). Environmental Systems Research Institute, Redlands

Farina A (2006) Principles and methods in landscape ecology, 2nd edn. Springer, Berlin

Forman R, Godron M (1986) Landscape ecology. Wiley, New York

Franklin J, Cromack Jr. K, Denison W, McKee A, Maser C, Sedell J, Swanson F, Juday G (1981) Ecological characteristics of oldgrowth Douglas-fir forests. General technical report PNW-118. USDA, Forest Service, Pacific Northwest Forest and Range Experiment Station

Geertsema M, Pojar J (2007) Influence of landslides on biophysical diversity - a perspective from British Columbia. Geomorphology 89:55-69 
Glenn N, Streutker D, Chadwick D, Thackray G, Dorsch S (2006) Analysis of LiDAR-derived topographic information for characterizing and differentiating landslide morphology and activity. Geomorphology 73:131-148

Grabowski D, Marciniec P, Mrozek T, Nescieruk P, Rączkowski W, Wójcik A, Zimnal Z (2008) Instrukcja opracowania Mapy osuwisk i terenów zagrożonych ruchami masowymi w skali 1:10 000. Państwowy Instytut Geologiczny. http://geoportal.pgi.gov.pl/css/ sopo/instr_oprac_motz.pdf. Accessed 25 May 2018

Guzzetti F, Carrara A, Cardinali M, Reichenbach P (1999) Landslide hazard evaluation: a review of current techniques and their application in a multi-scale study, Central Italy. Geomorphology 31:181-216. https://doi.org/10.1016/S0169-555X(99)00078-1

Hammer Ø, Harper DAT, Ryan PD (2001) PAST: paleontological statistics software package for education and data analysis. Palaentol Electron 4(1):1-9

Hjort J, Gordon J, Gray M, Hunter M Jr (2015) Why geodiversity matters in valuing nature's stage. Conserv Biol 29(3):630-639

Hoechstetter S, Walz U, Dang LH, Thinh NX (2008) Effects of topography and surface roughness in analyses of landscape structure-a proposal to modify the existing set of landscape metrics. Landsc Online 3:1-14

Hoechstetter S, Walz U, Dang LH, Thinh N (2011) Adapting lacunarity techniques for gradient-based analyses of landscape surfaces. Ecol Complex 8:229-238

Hyde P, Dubayah R, Walker W, Blair B, Hofton M, Hunsaker C (2006) Mapping forest structure for wildlife habitat analysis using multisensor (LiDAR, SAR/InSAR, ETM+, Quickbird) synergy. Remote Sens Environ 30:63-73

Karte des Königreichs Galizien und Lodomerien (1779-1783). Scale 1:28800. http://mapire.eu/en/map/firstsurvey. Accessed 25 May 2018

Kasai M, Ikeda M, Asahina T, Fujisawa K (2009) LiDAR-derived DEM evaluation of deep-seated landslides in a steep and rocky region of Japan. Geomorphology 113:57-69

MacMillan R, Pettapiece W, Nolan S, Goddard T (2000) A generic procedure for automatically segmenting landforms into landform elements using DEMs, heuristic rules and fuzzy logic. Fuzzy Sets Syst 113:81-109

Magurran AE (1988) Ecological diversity and its measurement. Croom Helm Ltd., London

Metzger J, Muller E (1996) Characterizing the complexity of landscape boundaries by remote sensing. Landsc Ecol 11(2):65-77

National water management authority. ISOK-IT System of the country's protection against extreme hazards. http://www.isok.gov.pl/ en/. Accessed 25 May 2018

Noss RF (1990) Indicators for monitoring biodiversity: a hierarchical approach. Conser Biol 4(4):355-364

Pawlak Z (1982) Rough Sets. Int J Inf Comput Sci 11:344-356

Pereira L, Gonçalves G (2010) Accuracy of a DTM derived from fullwaveform laser scanning data under unstructured eucalypt forest: a case study. FIG congress. Sydney, 11-16 April 2010

Pereira H, Belnap J, Böhm M, Brummitt N, Garcia-Moreno J, Gregory R, Martin L, Peng C, Proença V, Schmeller D, Swaay C (2017) Monitoring essential biodiversity variables at the species level. In: Walters M, Scholes R (eds) The GEO handbook on biodiversity observation networks. https://doi.org/10.1007/978-3-319-27288 $-7 \_4$

Polish Geological Institute-National Research Institute, Carpathian Branch. SOPO-landslide counteracting system. http://www.pgi. gov.pl/en/services/landslides.html. Accessed 25 May 2018

Reutebuch S, McGaughey R, Andersen H-E, Carson W (2003) Accuracy of a high-resolution lidar terrain model under a conifer forest canopy. Can J Remote Sens 29(5):527-535
Richter M (2009) To what extent do natural disturbances contribute to Andean plant diversity? A theoretical outline from the wettest and driest parts of the tropical Andes. Adv Geosci 22:95-105

Rowbotham D, Dudycha D (1998) GIS modelling of slope stability in Phewa Tal watershed. Nepal Geomorphol 26:151-170

Różycka M, Migoń P, Michniewicz A (2017) Topographic wetness index and terrain ruggedness index in geomorphic characterisation of landslide terrains, on examples from the sudetes, SW Poland. Zeitschrift für geomorphologie, Supplementary issues vol 61 Supplementary issue 2, pp 61-80. https://doi.org/10.1127/zfg_suppl /2016/0328

Schuster R, Highland L (2017) Overview of the effects of mass wasting on the natural environment. Environ Eng Geosci 13(1):25-44. https://doi.org/10.2113/gseegeosci.13.1.25

Schütz J-P, Saniga M, Diaci J, Vrška T (2016) Comparing close-tonature silviculture with processes in pristine forests: lessons from central Europe. Ann For Sci 73:911-921

Silverman B (1986) Density estimation for statistics and data analysis. Chapman and Hall, New York

Sittler B, Schellber S, Siepmann-Schinker D, Weinacker H (2006) Airborne laser scanning to generate $3 \mathrm{D}$ models of microrelief features for the purposes of forest ecological and archaeological surveys. In: Workshop on 3D remote sensing in forestry, 14th-15th Feb 2006, Vienna

Smith D (1962) The practice of silviculture 7th edn, the continuation of a work published as a 1st edn in March 1921 by Ralph C Hawley. Wiley, New York

Stereńczak K (2010) DTM generated from lidar data under forest conditions. A special joint symposium of ISPRS technical commission IV and AutoCarto in conjunction with ASPRS/CaGIS 2010 Fall specialty conference, November 15-19 2010, Orlando, Florida

Tarolli P, Sofia G, Fontana G (2012) Geomorphic features extraction from high-resolution topography: landslide crowns and bank erosion. Nat Hazards 61:65-83

Tüxen R, Ellenberg H (1937) Der systematische und ökologische gruppenvert. Ein beitrag zur begriffobildung und methodik der Pflanzensoziologie. Mitt Flor-Soz Arbeitsgem 3:171-184

von Ruette J, Papritz A, Lehmann P, Rickli C, Or D (2011) Spatial statistical modeling of shallow landslides-Validating predictions for different landslide inventories and rainfall events. Geomorphology 133:11-22

Walz U (2011) Landscape structure, landscape metrics and biodiversity. Living review in landscape research, 5,3 . http://lrlr.lands capeonline.de/Articles/lrlr-2011-3. Accessed 25 May 2018

Wang De, Bojie Fu, Kangshou Lu, Xiao L, Zhang Y, Feng X (2010) Multifractal analysis of land use pattern in space and time: a case study in the Loess Plateau of China. Ecol Complex 7:487-493

Wilson J, Gallant J (eds) (2000) Terrain analysis: principles and applications. Wiley, New York

Xia Y, Feng D, Zhao R (2006) Morphology-based multifractal estimation for texture segmentation. IEEE Trans Image Process 15(3):614-623

World Conservation Monitoring Centre (1992) Global biodiversity. United Nations Environment Programme Chapman and Hall.

Zabuski L, Thiel K, Bober L (1999) Osuwiska we fliszu Karpat polskich. Instytut Budownictwa Wodnego PAN

Zadeh L (1965) Fuzzy sets. Inf Control 8(3):338-353

Publisher's Note Springer Nature remains neutral with regard to jurisdictional claims in published maps and institutional affiliations. 